\title{
Prediction of the Fragmentation Pathway of Valsartan Protonated Ion
}

\author{
Dev Kant Shandilya ${ }^{*}$, Rekha Israni1, Peter Edward Joseph ${ }^{2}$ \\ ${ }^{1}$ Department of Research, Bhagwant University, Ajmer, India \\ ${ }^{2}$ Department of Chemistry, ST. Johns College, Agra, India \\ Email: ^shandilya@yahoo.com, devkantshandilya@hotmail.com
}

How to cite this paper: Shandilya, D.K., Israni, R. and Joseph, P.E. (2018) Prediction of the Fragmentation Pathway of Valsartan Protonated Ion. Open Access Library Journal, 5: e4764.

https://doi.org/10.4236/oalib.1104764

Received: July 9, 2018

Accepted: September 27, 2018

Published: September 30, 2018

Copyright $\odot 2018$ by authors and Open Access Library Inc.

This work is licensed under the Creative Commons Attribution International License (CC BY 4.0).

http://creativecommons.org/licenses/by/4.0/

\begin{abstract}
Introduction: A fragmentation pathway of valsartan protonated ion proposed based on rational interpretation workflows. Method: The mass spectral data (MS, MS/MS, and $\mathrm{MS}^{3}$ ) of valsartan protonated ion, were attained by electrospray positive ionization with flow injection analysis; using liquid chromatography systems hyphenated with hybrid tandem mass spectrometer (Q-trap). Results: The pathway of fragmentation was established using product ions of the protonated ion; elemental composition, molecular structure and mechanism of formation for significant product ions were proposed. A pathway was proposed based on the MS/MS and MS ${ }^{3}$ spectral data in combination with basic interpretation rules and rational workflows. Conclusion: Workflow used for data interpretation can be useful for writing the fragmentation pathway, a mechanism for the formation of fragments, and can be applied for mass spectral data interpretation of similar small organic molecules.
\end{abstract}

\section{Subject Areas}

Analytical Chemistry, Chemical Engineering and Technology

\section{Keywords}

Valsartan, Small Organic Molecules, Fragmentation Pathway, Protonated Ion, Fragmentation, Interpretation

\section{Introduction}

Nowadays the use of Mass spectrometry (MS) is amplified in the analytical research laboratories of pharmaceutical research and development. Mass spectrometry plays an essential role for the characterization and identification of small and large drug molecules. Understanding mass spectrometry data interpretation became necessary for the research scientist working in the field of pharmaceuti- 
cal research. The application of mass spectrometry is kept on increasing day by day. Therefore in this study spectral data generated using advanced mass spectrometric systems, along with reasonable data interpretation is beneficial for comprehensive structural analysis study, i.e., to study the fragments and to propose a pathway [1]-[13].

The focus of this study solely towards the mass spectral data interpretation, during this study unit-resolution tandem mass analyzer (Q-trap) mass spectrometry systems with trap functionality, was used. Q-trap analyzer was very helpful to generate $\mathrm{MS}^{3}$ spectral data by using the third quadrupole as a trap. $\mathrm{MS}^{3}$ information directed to write a fragmentation pathway for parent and product ions. A small nitrogenous organic molecule with a carboxylic acid functional group; valsartan was selected for this study and spectral data were generated using positive ion mode. Followed by prediction of fragmentation pathway of protonated ion, using similar methodology or workflow as described or applied in [14] [15] [16].

Mass spectrometry spectral data interpretation is the most time taking and complicated process. So, here use of a step by step, rational workflow to interpret MS (protonated peak) and MS/MS (collision-induced dissociation or fragmentation), and $\mathrm{MS}^{3}$ spectra of valsartan (small drug molecule) depicted.

Valsartan [17] [18] [19] is an angiotensin-receptor blocker (ARB) that may be used to treat a variety of cardiac conditions including hypertension, diabetic nephropathy, and heart failure. Valsartan lowers blood pressure by antagonizing the renin-angiotensin-aldosterone system (RAAS); it competes with angiotensin II for binding to the type-1 angiotensin II receptor (AT1) subtype and prevents the blood pressure increasing effects of angiotensin II. Unlike angiotensin-converting enzyme (ACE) inhibitors, ARBs do not have the adverse effect of a dry cough. Valsartan may be used to treat hypertension, isolated systolic hypertension, left ventricular hypertrophy and diabetic nephropathy. It may also be used as an alternative agent for the treatment of heart failure, systolic dysfunction, myocardial infarction and coronary artery disease (drug bank and rxlist). Valsartan is chemically described as $\mathrm{N}$-(1-oxopentyl)- $\mathrm{N}$-[ [2'-(1H-tetrazol-5-yl) [1,1'-biphenyl]-4-yl]methyl]-L-valine. Its empirical formula is $\mathrm{C}_{24} \mathrm{H}_{29} \mathrm{~N}_{5} \mathrm{O}_{3}$, its molecular weight is 435.5, and its structural formula presented in Figure 1.

During this study mass, spectral data of valsartan was generated using electrospray ionization, and collision-induced dissociation; followed by interpretation, workflow [15] and basic rules were used for the interpretation of the full scan atmospheric pressure ionization mass spectra (MS), collision-induced dissociation fragmentation spectra (MS/MS) and $\mathrm{MS}^{3}$ data.

\section{Experimental}

\subsection{Drug Sample}

Valsartan was extracted from the generic dosage form. A final concentration was about ten $\mu \mathrm{g} / \mathrm{ml}$ in a mixture of water, methanol, and acetonitrile. 


\subsection{Chemicals and Reagents}

The ultrapure water (18.2 M $\Omega$ ) was obtained using MilliQ apparatus from Millipore (Milford, USA), acetonitrile HPLC grade and the HPLC grade methanol was purchased from J. T. Baker.

\subsection{Instrumentation}

Shimadzu Prominence 20 AD HPLC (Kyoto Japan) coupled with Q-trap 5500 (AB SCIEX), equipped with electrospray ionization source (ESI) were used for this analysis.

\subsection{Chromatographic and Mass Spectrometric Conditions}

The experimental data (MS, MS/MS and $\mathrm{MS}^{3}$ spectral data) of valsartan was generated using high-performance liquid chromatography (HPLC) coupled with Q-trap mass analyzer via Flow Injection Analysis (FIA) mode and Electro-spray Ionization (ESI+) ion source. Collision-induced fragmentation (CID) technique in collision cell (Q2) of Q-trap mass spectrometer was used for the fragmentation of protonated molecular ion into further fragments. The fragmentation pathways are preferably based on even-electron (EE) and least favorable to the formation of protonated ions in spectra, EE ions will generally result from the charge migration or transfer across the cleavage sites, rearrangement and multiple bond cleavage are common in CID spectra [8]-[13]. Interpretation workflow of [15] was applied for data interpretation. The same work flow can also be applied for de-protonated ions or negative ionization mode [20].

\section{Results and Discussion}

The mass spectrometry technique is a modern method for the identification of small molecules and their impurities. The full scan MS and product ion spectra of valsartan were obtained from experiments. Figure 1 shows the ESI+ mass spectrum (MS) of valsartan acquired using ESI (+ve). The protonated ion peak appeared at $\mathrm{m} / z$ 436.2 Da as $[\mathrm{M}+\mathrm{H}]^{+}$(calculated formula $\mathrm{C}_{24} \mathrm{H}_{30} \mathrm{~N}_{5} \mathrm{O}_{3}^{+}$). The protonated ion peak was further confirmed by calculating the mass difference with an adduct ion at $\mathrm{m} / z 458.1$ as $[\mathrm{M}+\mathrm{Na}]^{+}$and $474.1[\mathrm{M}+\mathrm{K}]^{+}$as exhibited in MS spectrum.

The MS/MS spectrum of valsartan was acquired at collision energy (CE) 10 , 20, and 30; to understand and differentiate between the low and high energy fragments and MS/MS spectra of $\mathrm{m} / \mathrm{z} 436.2$ at different collision energy were presented in Figures 2-4 and summarized in Table 1.

MS/MS spectra in Figures 2-4 showing the shift of low energy fragments to high energy fragments, aforesaid MS/MS information along with $\mathrm{MS}^{3}$ was helpful for writing the fragmentation pathway. During CID fragmentation of parent ion $436.2(\mathrm{M}+\mathrm{H})^{+}$ion fragmented into 11 fragments (9 major and 2 trace); $\mathrm{m} / \mathrm{z}$ 418.2 (PI-1), 408.3 (PI-2), 390.2 (PI-3), 362.4 (PI-4), 352.2 (PI-5), 306.2 (PI-6), 291.1 (PI-7), 235.1 (PI-8), 207.0 (PI-9), 190.0 and 180.0.

Major productions of MS/MS m/z 418.2 (PI-1), 362.4 (PI-4), 352.2 (PI-5), 306.4 (PI-6) and 291.1 (PI-7) are subjected of $\mathrm{MS}^{3}$ analysis, and $\mathrm{MS}^{3}$ spectra are 
presented in Figures 5-10. The fragmentation outcome of $\mathrm{MS}^{3}$ analysis summarized in Table 2. During $\mathrm{MS}^{3}$ analysis four new fragments 345.1 (PI-10), 194.1 (PI-11), 192.1 (PI-12) and 167.1 (PI-13). Fragmentation of PI-10 fragment ion $(\mathrm{m} / \mathrm{z} 345)$ obtained and presented in Figure 8. Based on MS/MS and $\mathrm{MS}^{3}$ spectral data, fragmentation pathway was predicted or depicted and presented in Figure 11 and interpretation of fragment ions, presented in Table 1 and Table 2. Fragmentation pathway presented in Figure 11, for medium and low molecular weight fragments there are multiple source for formation as presented in $\mathrm{Ta}$ ble 2 ( $\mathrm{MS}^{3}$ information). Proposed mechanism for the formation of all significant fragment ions PI-1 to PI-13 presented in Figures 12-24.

Table 1. MS/MS data interpretation of Valsartan protonated ion.

\begin{tabular}{|c|c|c|c|c|c|c|c|c|c|c|}
\hline \multirow{2}{*}{$\begin{array}{c}\text { Parent } \\
\text { ion }(m / z)\end{array}$} & \multirow{2}{*}{$\mathrm{CE}$} & \multicolumn{9}{|c|}{ Product ions $(m / z)$} \\
\hline & & PI-1 & PI-2 & PI-3 & PI-4 & PI-5 & PI-6 & PI-7 & PI-8 & PI-9 \\
\hline \multirow{3}{*}{$\begin{array}{c}436.2 \\
\mathrm{C}_{24} \mathrm{H}_{30} \mathrm{~N}_{5} \mathrm{O}_{3}^{+}\end{array}$} & 10 & 418.2 & $408.3 \mathrm{C}_{22} \mathrm{H}_{26} \mathrm{~N}_{5} \mathrm{O}_{3}^{+}$ & - & 362.4 & 352.2 & 306.2 & 291.1 & 235.1 & - \\
\hline & 20 & 418.2 & 408.3 & 390.2 & 362.2 & 352.2 & 306.1 & 291.1 & 235.0 & 207.0 \\
\hline & 30 & - & - & - & 362.2 & 352.2 & 306.1 & 291.1 & 235.0 & 207.0 \\
\hline
\end{tabular}

$\mathrm{CE}=$ Collision energy; $\mathrm{PI}=$ product ion

Table 2. Fragment ions (MS3) interpretation.

\begin{tabular}{|c|c|c|c|c|c|c|c|}
\hline $\begin{array}{c}\text { Measured Mass }(m / z) \\
(M S / M S)\end{array}$ & ID & $\begin{array}{c}\text { Measured } \\
\text { Mass }(m / z)\end{array}$ & $\begin{array}{l}\text { Electron } \\
\text { Paring }\end{array}$ & $\begin{array}{c}\text { Nitrogen } \\
\text { Rule }\end{array}$ & $\begin{array}{c}\text { No. of } \\
\text { Nitrogen (s) }\end{array}$ & $\begin{array}{l}\text { Proposed } \\
\text { Formula }\end{array}$ & $\begin{array}{l}\text { Calculated } \\
\text { Mass }\end{array}$ \\
\hline & PI-3 & 390.0 & $\mathrm{EE}$ & $\mathrm{ON}$ & 5 & $\mathrm{C}_{22} \mathrm{H}_{24} \mathrm{~N}_{5} \mathrm{O}_{2}^{+}$ & 390.2 \\
\hline & PI-4 & 362.2 & $\mathrm{EE}$ & ON & 5 & $\mathrm{C}_{20} \mathrm{H}_{20} \mathrm{~N}_{5} \mathrm{O}_{2}^{+}$ & 362.2 \\
\hline 418 (PI-1) & PI-10 & 345.1 & $\mathrm{OE}$ & ON & 5 & $\mathrm{C}_{20} \mathrm{H}_{19} \mathrm{~N}_{5}{ }^{+}$ & 345.2 \\
\hline $\mathrm{C}_{24} \mathrm{H}_{28} \mathrm{~N}_{5} \mathrm{O}_{2}^{+}$ & PI-6 & 306.1 & $\mathrm{EE}$ & ON & 5 & $\mathrm{C}_{18} \mathrm{H}_{20} \mathrm{~N}_{5}^{+}$ & 306.2 \\
\hline \multirow[t]{3}{*}{ Calculated: 418.2} & PI-7 & 291.2 & $\mathrm{OE}$ & ON & 5 & $\mathrm{C}_{17} \mathrm{H}_{17} \mathrm{~N}_{5}^{\cdot+}$ & 291.1 \\
\hline & PI- 8 & 235.0 & $\mathrm{EE}$ & EN & 4 & $\mathrm{C}_{14} \mathrm{H}_{11} \mathrm{~N}_{4}^{+}$ & 235.1 \\
\hline & PI-9 & 207.2 & $\mathrm{EE}$ & $\mathrm{EN}$ & 2 & $\mathrm{C}_{14} \mathrm{H}_{11} \mathrm{~N}_{2}^{+}$ & 207.1 \\
\hline $362(\mathrm{PI}-4)$ & PI-4 & 362.2 & $\mathrm{EE}$ & ON & 5 & $\mathrm{C}_{20} \mathrm{H}_{19} \mathrm{~N}_{5} \mathrm{O}^{+}$ & 362.2 \\
\hline $\mathrm{C}_{20} \mathrm{H}_{20} \mathrm{~N}_{5} \mathrm{O}_{2}^{+}$ & PI-10 & 345.1 & $\mathrm{OE}$ & ON & 5 & $\mathrm{C}_{20} \mathrm{H}_{19} \mathrm{~N}_{5}^{\cdot+}$ & 345.2 \\
\hline Calculated: 362.2 & PI-7 & 291.1 & $\mathrm{OE}$ & ON & 5 & $\mathrm{C}_{17} \mathrm{H}_{17} \mathrm{~N}_{5}^{\cdot+}$ & 291.1 \\
\hline 352 (PI-5) & PI-6 & 306.1 & $\mathrm{EE}$ & ON & 5 & $\mathrm{C}_{18} \mathrm{H}_{20} \mathrm{~N}_{5}^{+}$ & 306.2 \\
\hline $\mathrm{C}_{19} \mathrm{H}_{22} \mathrm{~N}_{5} \mathrm{O}_{2}^{+}$ & PI-8 & 235.1 & $\mathrm{EE}$ & EN & 4 & $\mathrm{C}_{14} \mathrm{H}_{11} \mathrm{~N}_{4}^{+}$ & 235.1 \\
\hline Calculated: 352.2 & PI-9 & 207.1 & $\mathrm{EE}$ & EN & 2 & $\mathrm{C}_{14} \mathrm{H}_{11} \mathrm{~N}_{2}^{+}$ & 207.1 \\
\hline 345.0 (PI-10) & PI-6 & 306.2 & $\mathrm{EE}$ & $\mathrm{ON}$ & 5 & $\mathrm{C}_{18} \mathrm{H}_{20} \mathrm{~N}_{5}^{+}$ & 306.2 \\
\hline \multirow{2}{*}{$\begin{array}{l}\mathrm{C}_{20} \mathrm{H}_{19} \mathrm{~N}_{5} \cdot+ \\
\left(\mathrm{MS}^{3}\right)\end{array}$} & PI-8 & 235.1 & $\mathrm{EE}$ & EN & 4 & $\mathrm{C}_{14} \mathrm{H}_{11} \mathrm{~N}_{4}^{+}$ & 235.1 \\
\hline & PI-9 & 207.1 & $\mathrm{EE}$ & EN & 2 & $\mathrm{C}_{14} \mathrm{H}_{11} \mathrm{~N}_{2}^{+}$ & 207.1 \\
\hline 306 (PI-6) & PI-8 & 235.1 & $\mathrm{EE}$ & EN & 4 & $\mathrm{C}_{14} \mathrm{H}_{11} \mathrm{~N}_{4}^{+}$ & 235.1 \\
\hline Calculated: 306.2 & PI-9 & 207.1 & $\mathrm{EE}$ & EN & 2 & $\mathrm{C}_{14} \mathrm{H}_{11} \mathrm{~N}_{2}^{+}$ & 207.1 \\
\hline \multirow{4}{*}{$\begin{array}{c}\text { 291(PI-7) } \\
\mathrm{C}_{17} \mathrm{H}_{17} \mathrm{~N}_{5}{ }^{++} \\
\text {Calculated: } 291.1\end{array}$} & PI-8 & 235.1 & $\mathrm{EE}$ & EN & 4 & $\mathrm{C}_{14} \mathrm{H}_{11} \mathrm{~N}_{4}^{+}$ & 235.1 \\
\hline & PI-11 & 194.1 & $\mathrm{EE}$ & $\mathrm{ON}$ & 1 & $\mathrm{C}_{14} \mathrm{H}_{12} \mathrm{~N}^{+}$ & 194.1 \\
\hline & PI-12 & 192.1 & $\mathrm{EE}$ & ON & 1 & $\mathrm{C}_{14} \mathrm{H}_{10} \mathrm{~N}^{+}$ & 192.1 \\
\hline & PI-13 & 167.1 & $\mathrm{EE}$ & EN & 0 & $\mathrm{C}_{13} \mathrm{H}_{11}^{+}$ & 167.1 \\
\hline
\end{tabular}

EE: even electron; EN: even nitrogen; ON: odd nitrogen; PI: Product ion. 


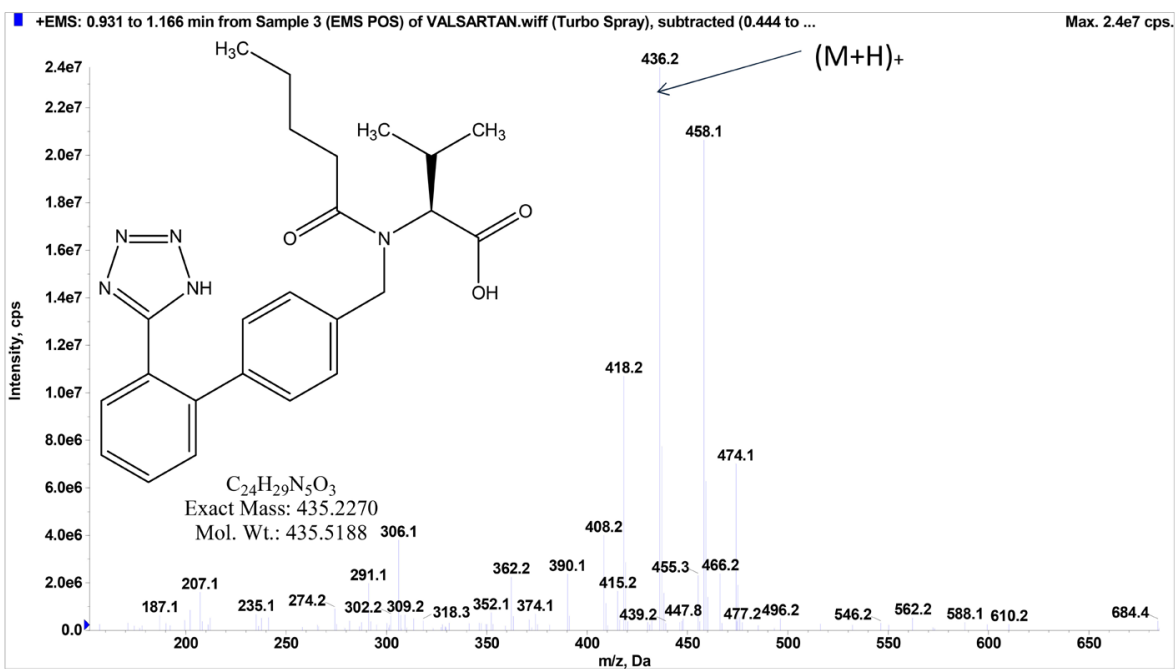

Figure 1. Positive ion mode mass spectra of Valsartan.

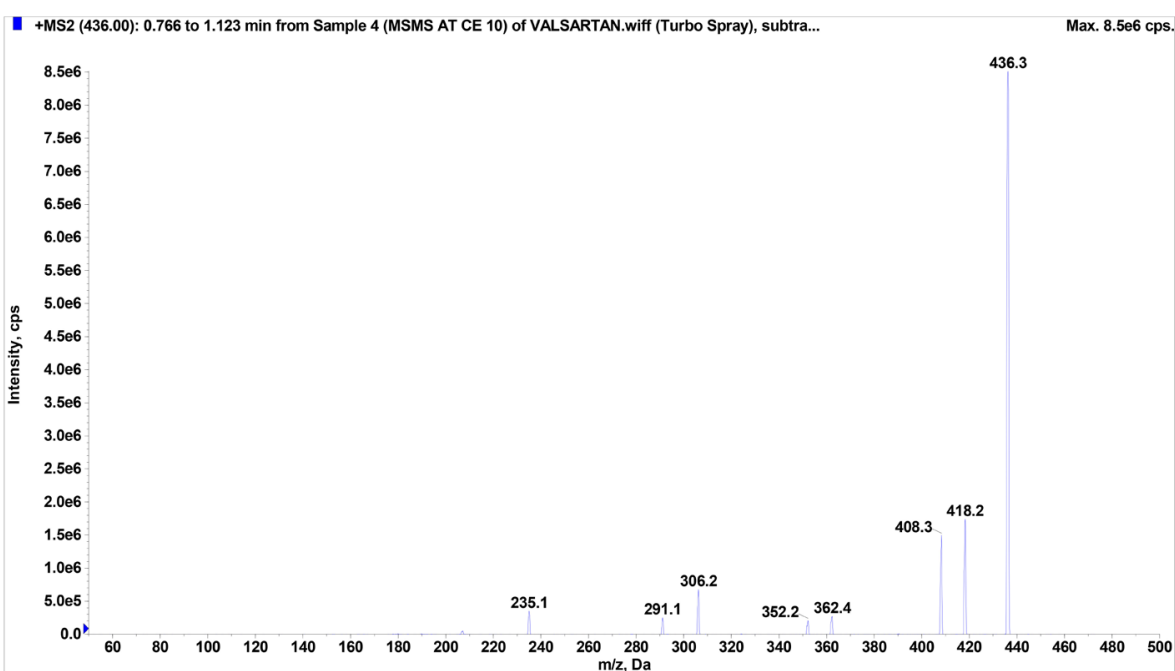

Figure 2. MS/MS spectra of valsartan $(m / z-436)$ at CE 10.

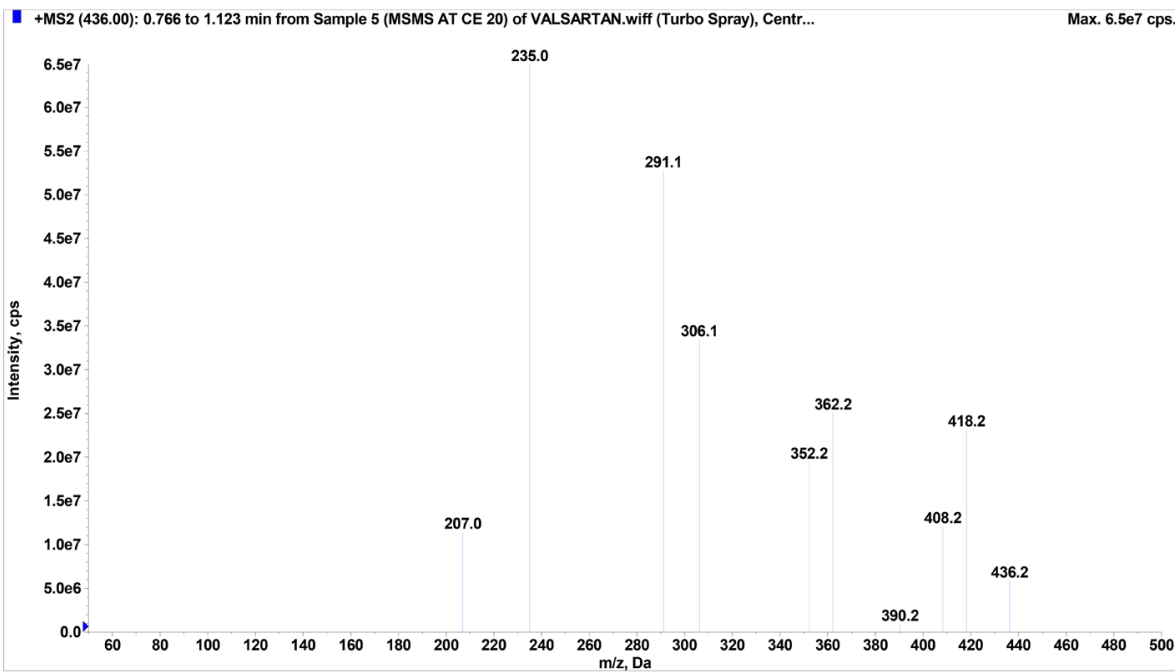

Figure 3. MS/MS spectra of valsartan $(m / z-436)$ at CE 20. 


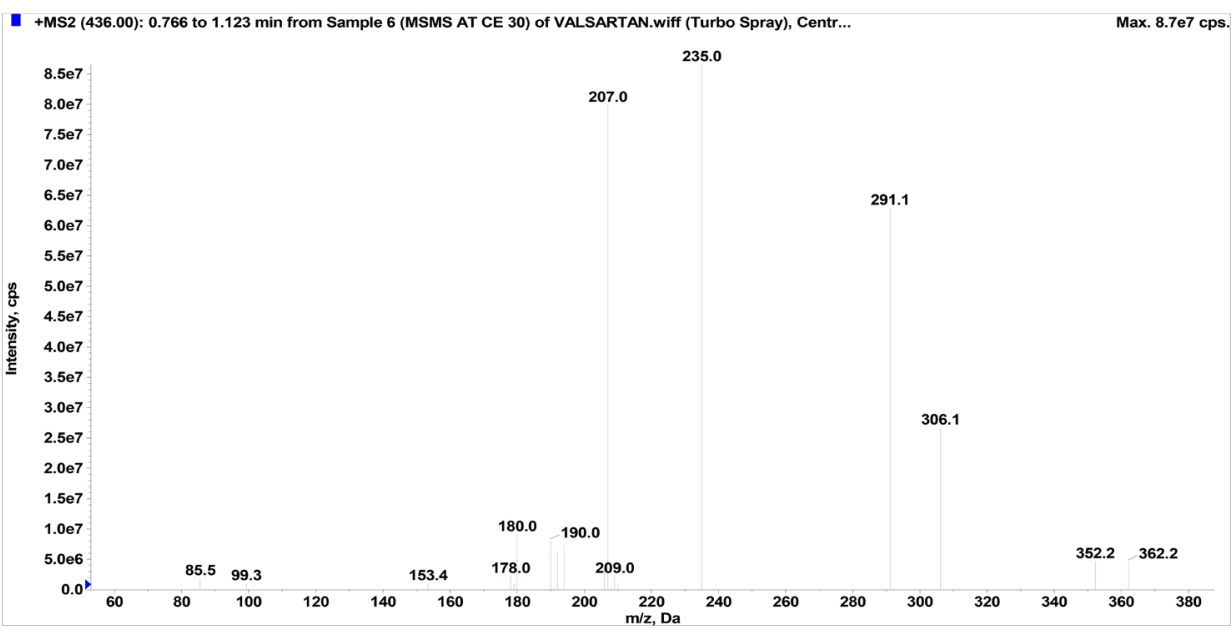

Figure 4. MS/MS spectra of valsartan $(\mathrm{m} / \mathrm{z}-436)$ at CE 30.

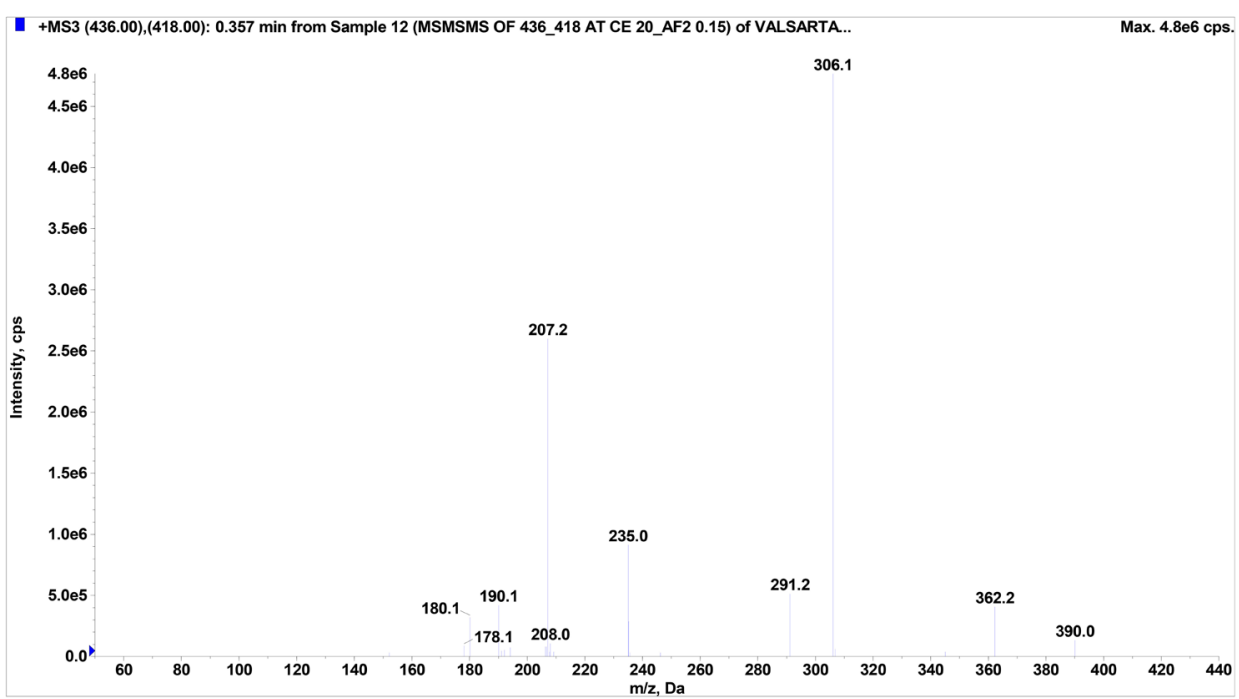

Figure 5. Fragment ion spectra (MS3) of product ion PI-1 (m/z-418 (Parent 436)).

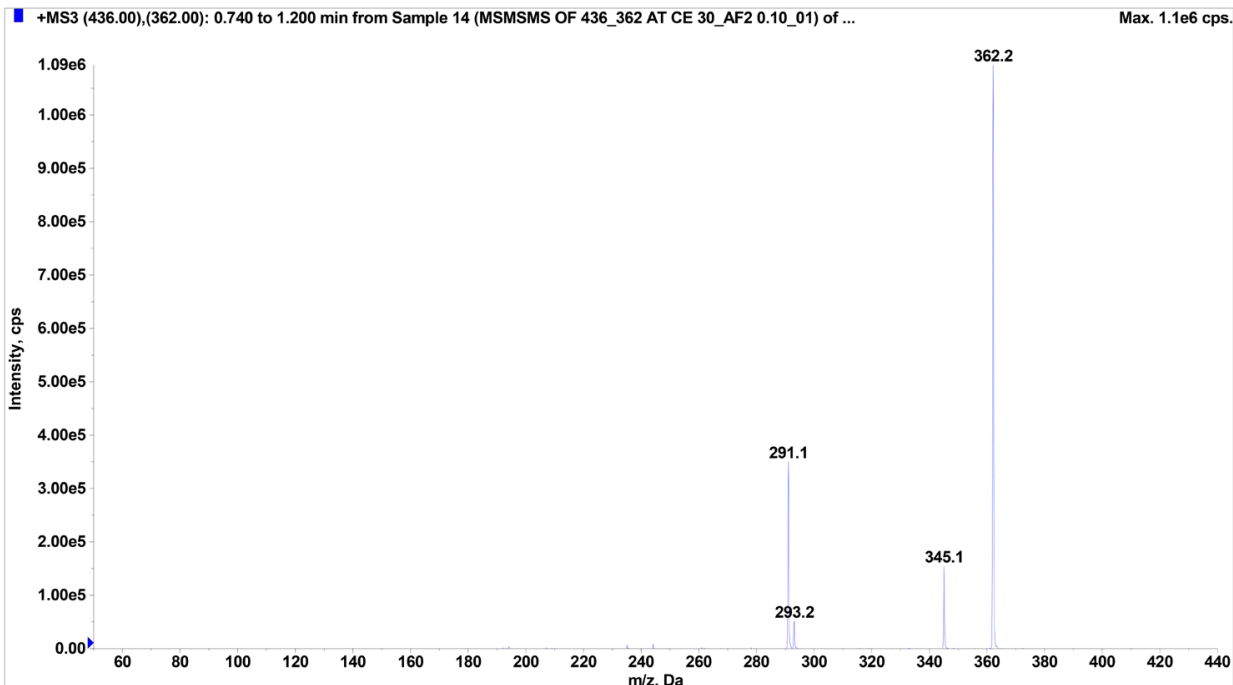

Figure 6. Fragment ion spectra (MS3) of product ion PI-4 (m/z-362 (Parent 436)). 


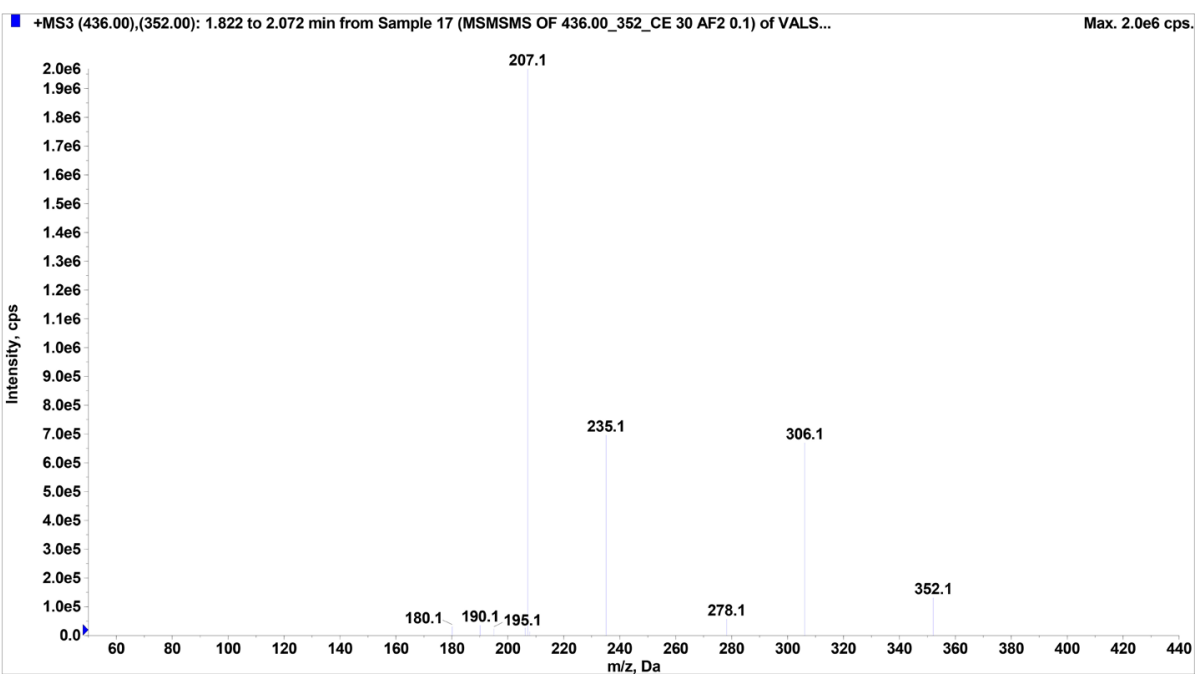

Figure 7. Fragment ion spectra $\left(\mathrm{MS}^{3}\right)$ of product ion PI-4 ( $\mathrm{m} / \mathrm{z}-352$ (Parent 436$\left.)\right)$.

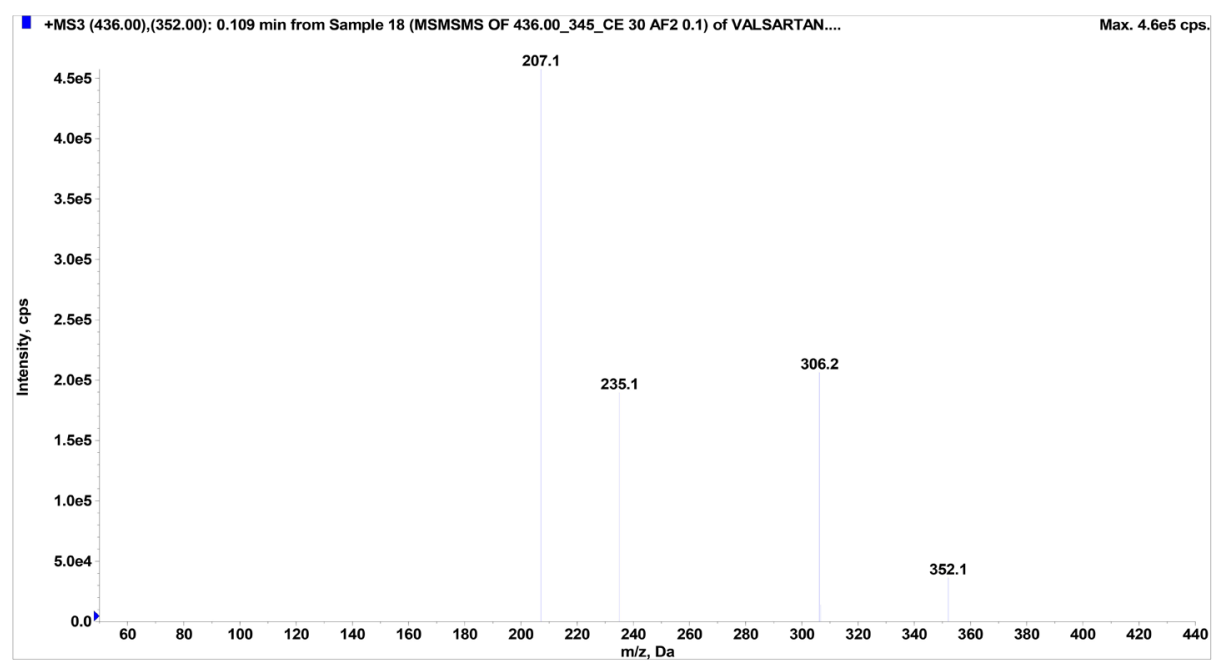

Figure 8. Fragment ion spectra (MS3) of product ion PI-10 ( $\mathrm{m} / \mathrm{z}-345$ (Parent 436$)$ ).

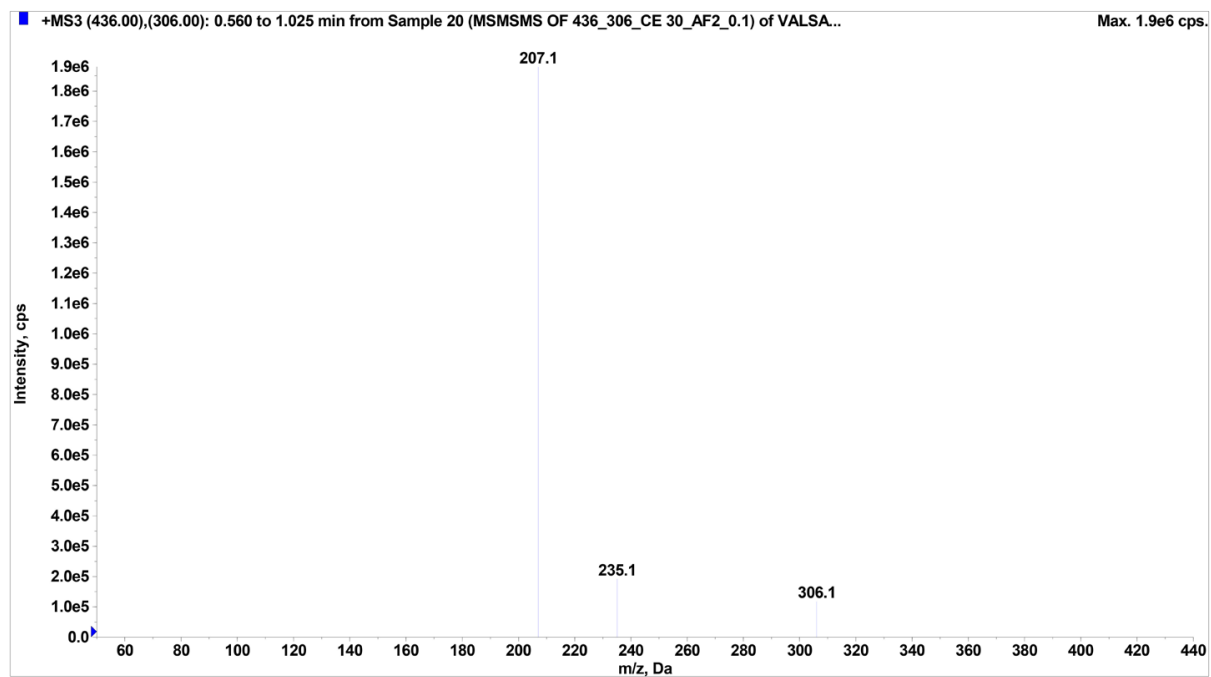

Figure 9. Fragment ion spectra (MS3) of product ion PI-6 ( $\mathrm{m} / \mathrm{z}-306$ (Parent 436)). 


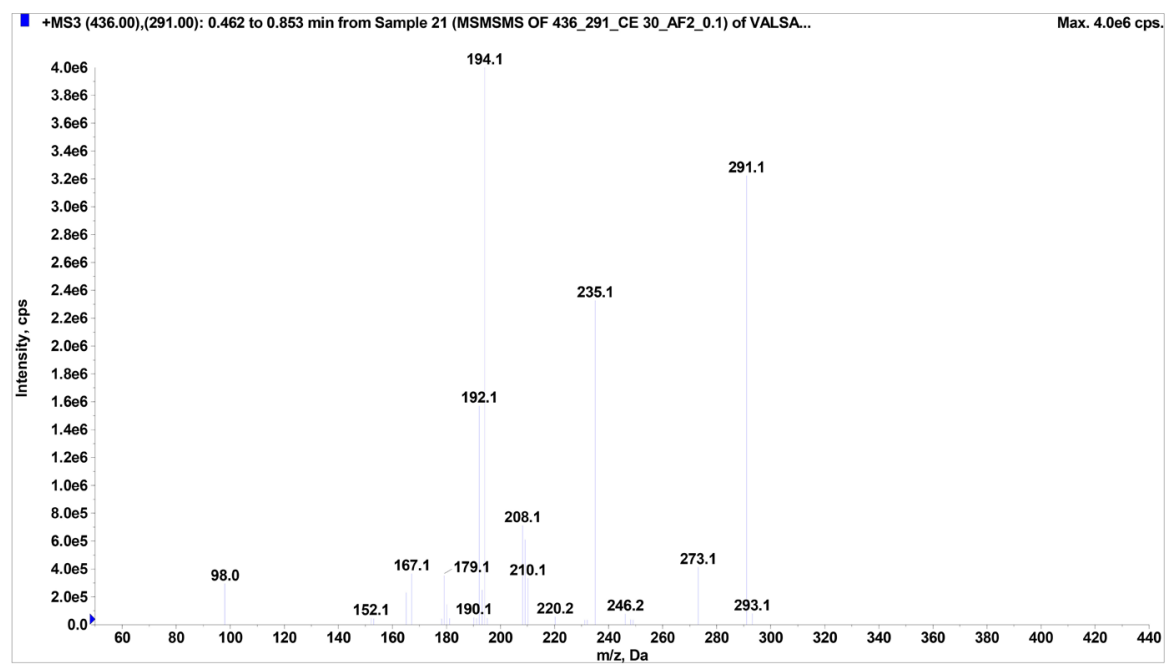

Figure 10. Fragment ion spectra (MS3) of product ion PI-7 ( $\mathrm{m} / \mathrm{z}-291$ (Parent 436$)$ ).

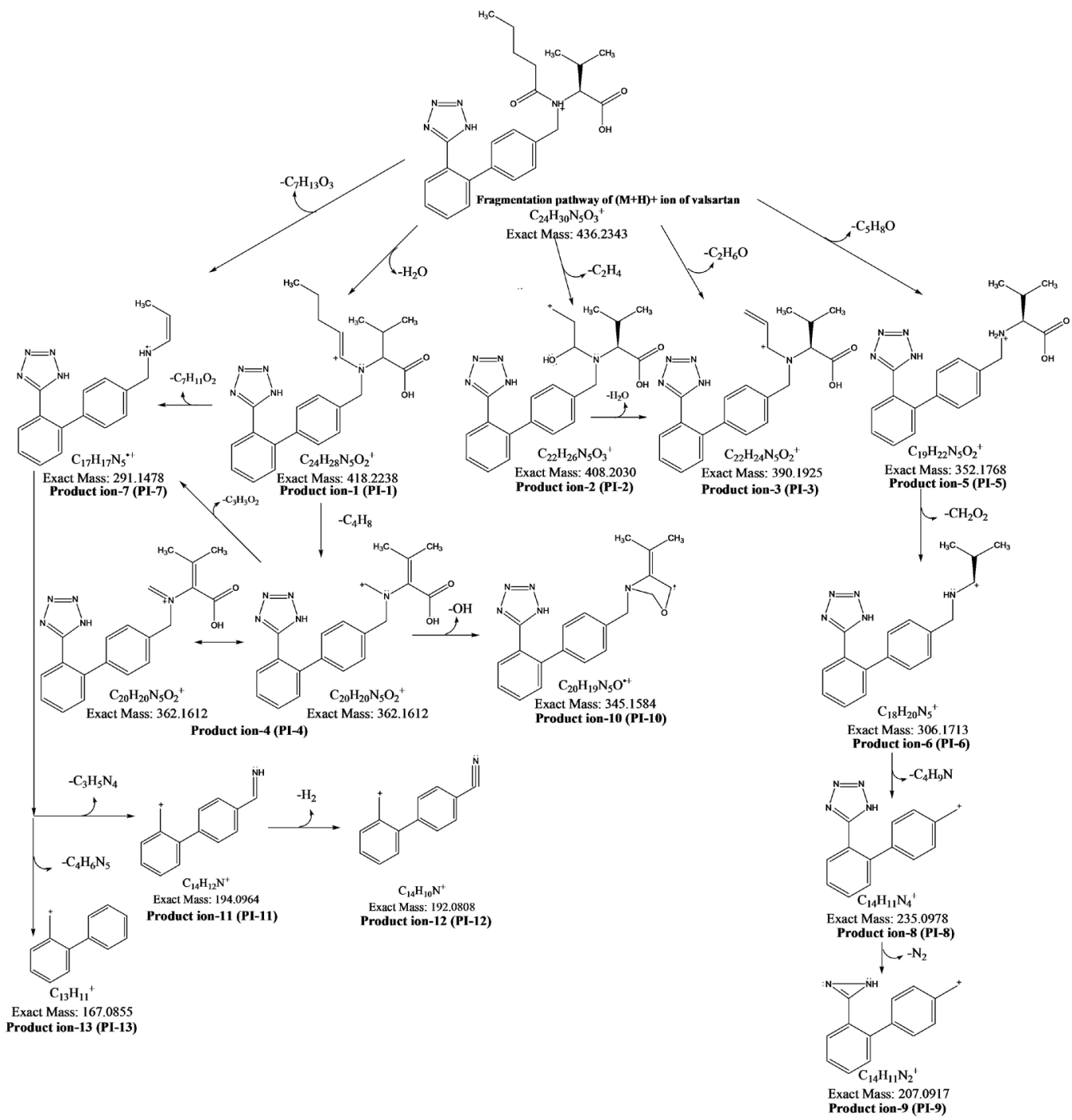

Figure 11. Pathway for the formation of fragment ions (PI-1 to P13) of valsartan, predicted based on $\mathrm{MS}^{3}$ spectral data. 


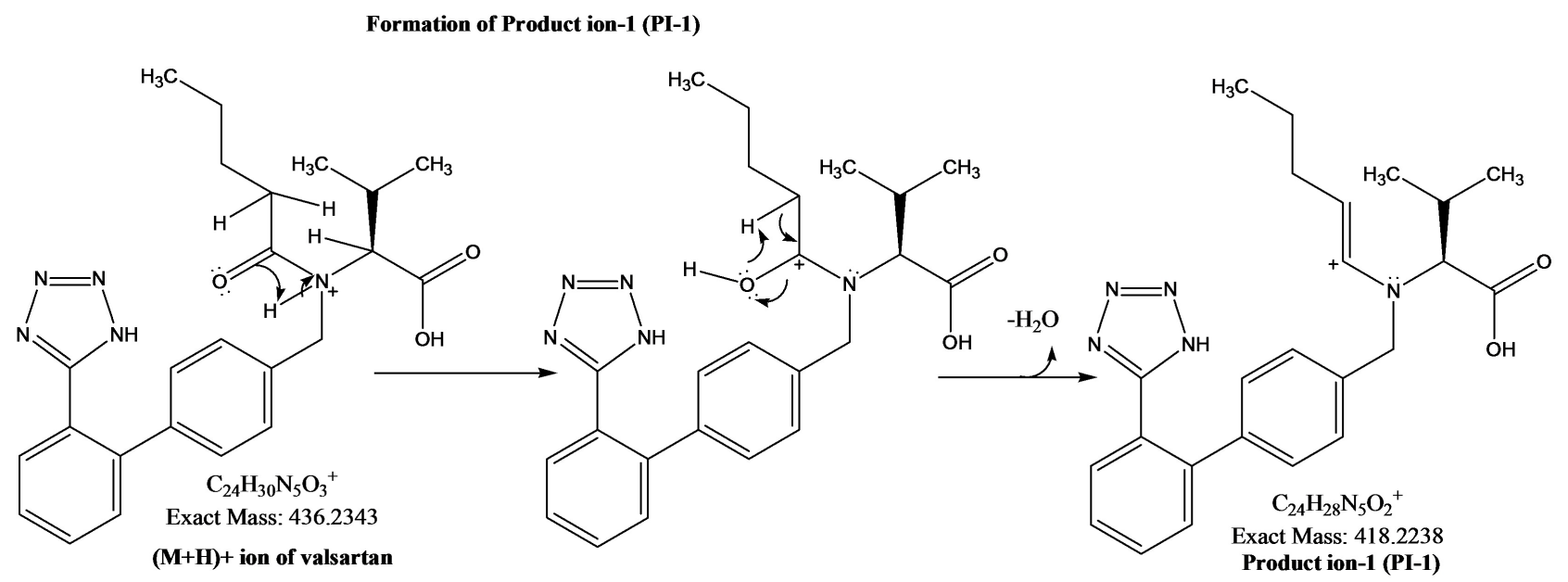

Figure 12. Mechanism for the formation of fragment PI-1.
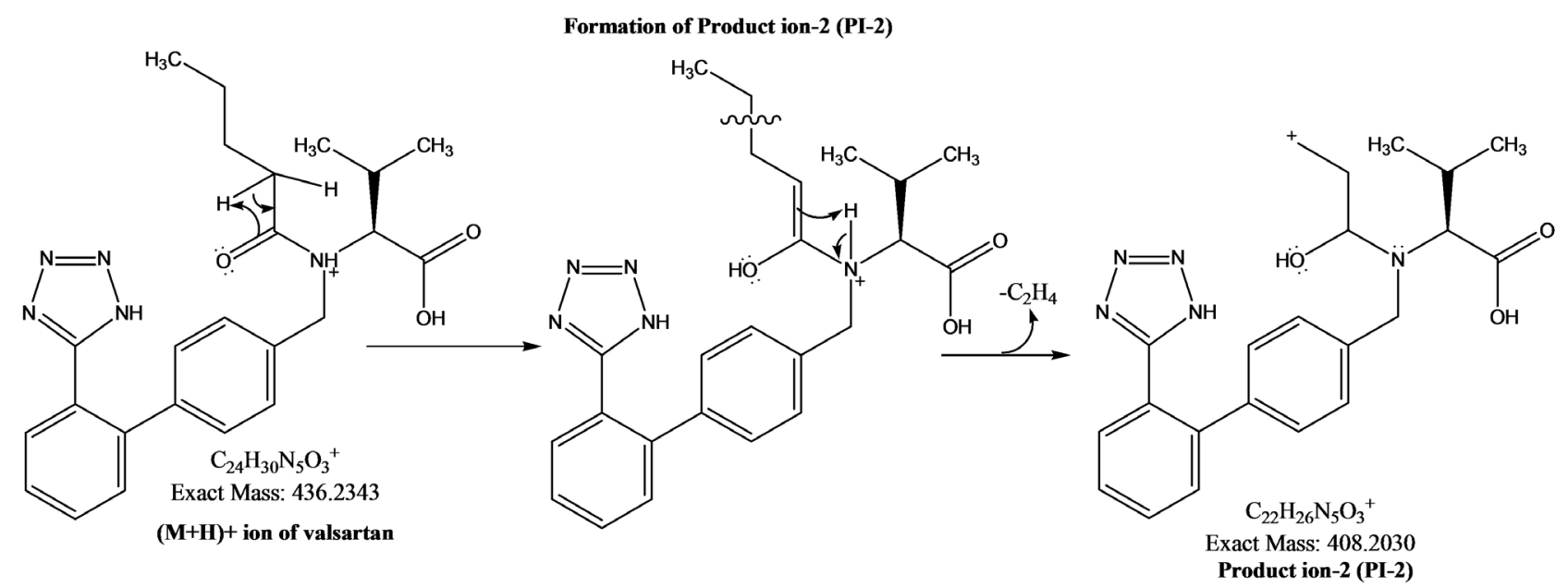

Figure 13. Mechanism for the formation of fragment PI-2.

Formation of Product ion-3 (PI-3)

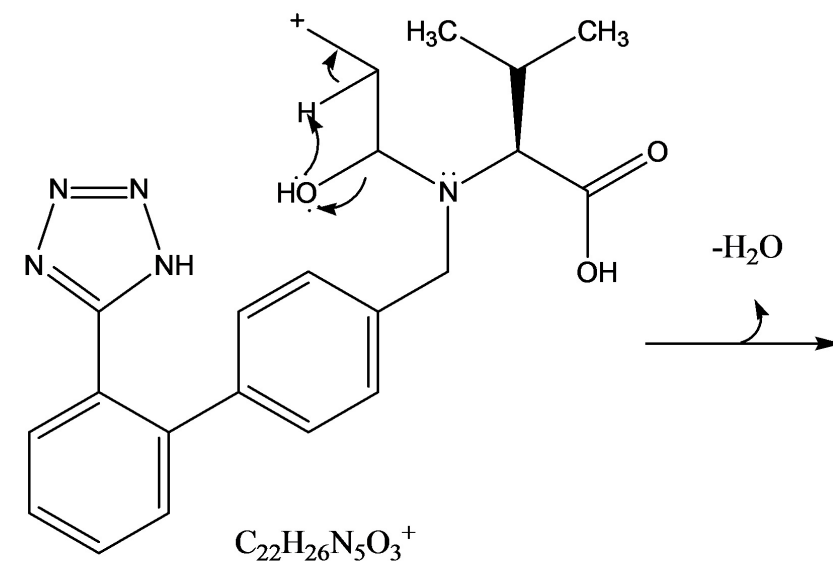

Exact Mass: 408.2030

Product ion-2 (PI-2)<smiles>C=C[CH]N(Cc1ccc(-c2ccccc2-c2nnn[nH]2)cc1)[C@@H](C(=O)O)C(C)C</smiles>

Exact Mass: 390.1925

Product ion-3 (PI-3)

Figure 14. Mechanism for the formation of fragment PI-3. 

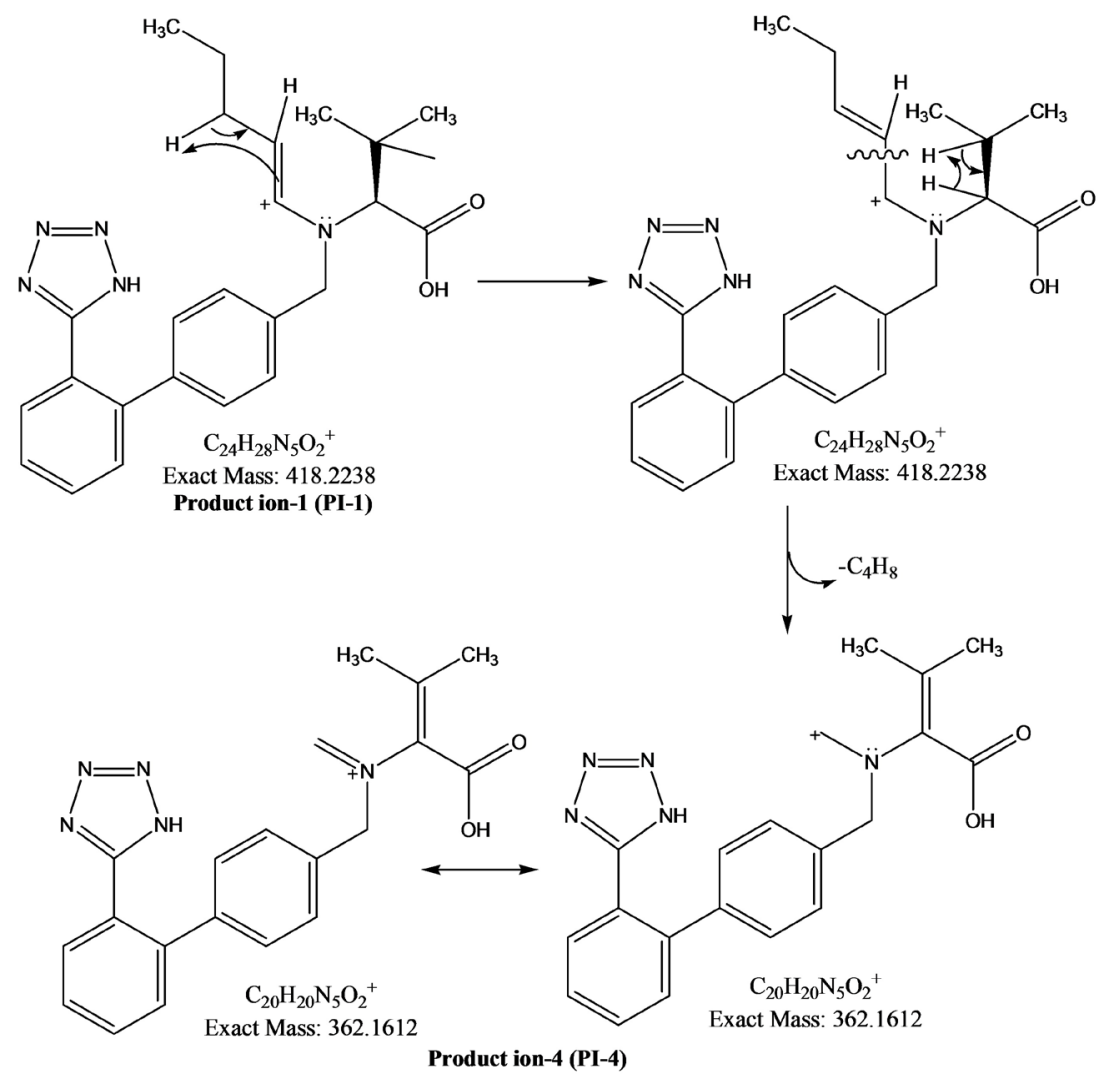

Figure 15. Mechanism for the formation of fragment PI-4..

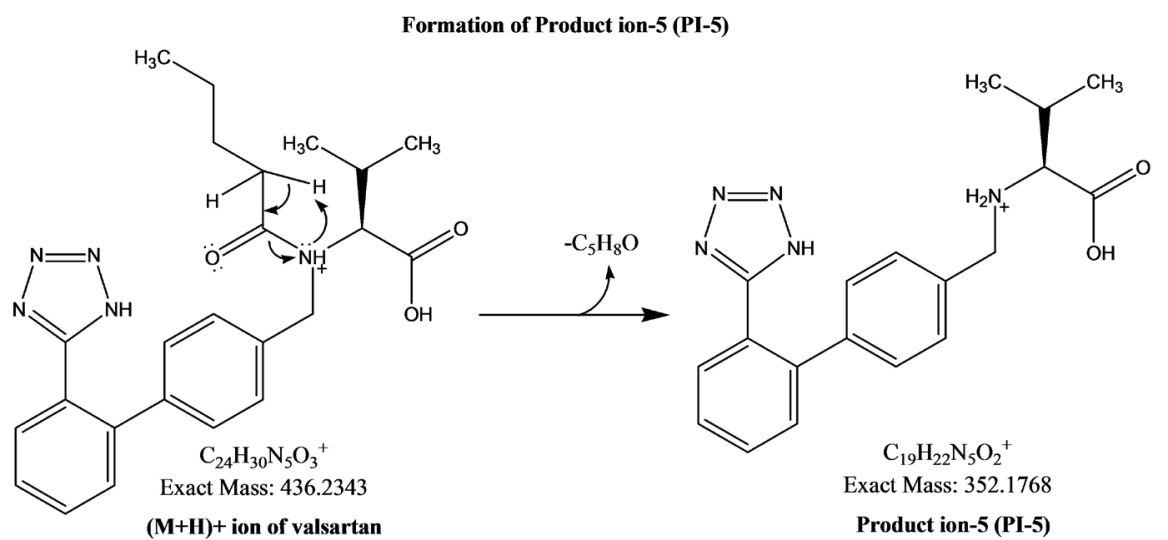

Figure 16. Mechanism for the formation of fragment PI-5.

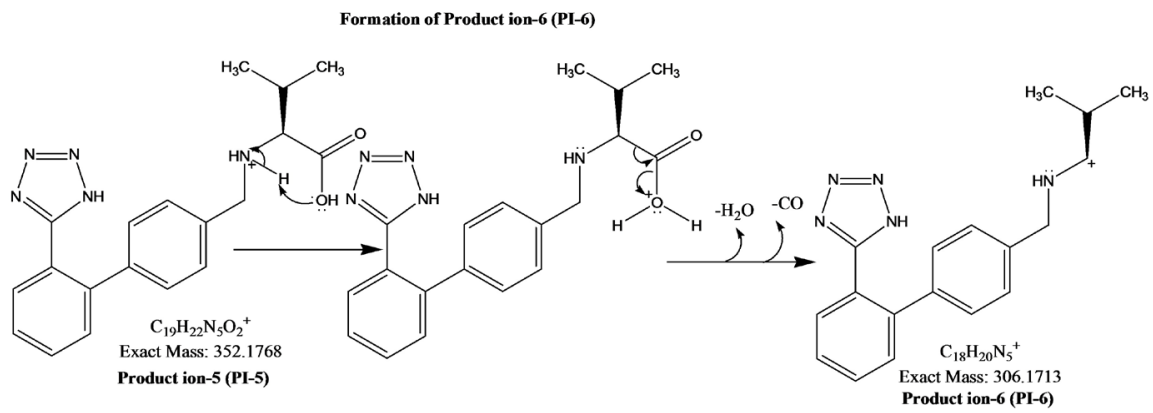

Figure 17. Mechanism for the formation of fragment PI-6. 


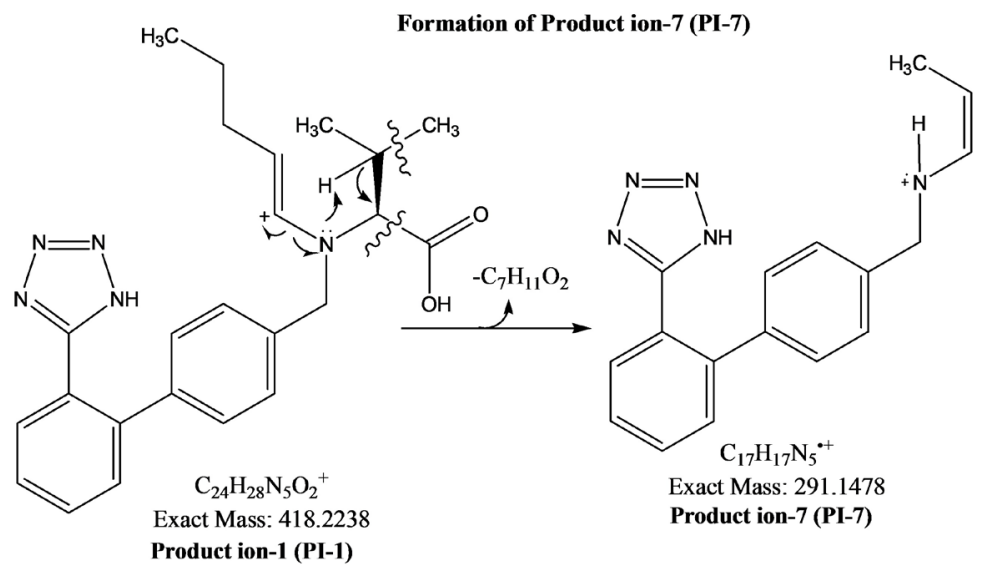

Figure 18. Mechanism for the formation of fragment PI-7.

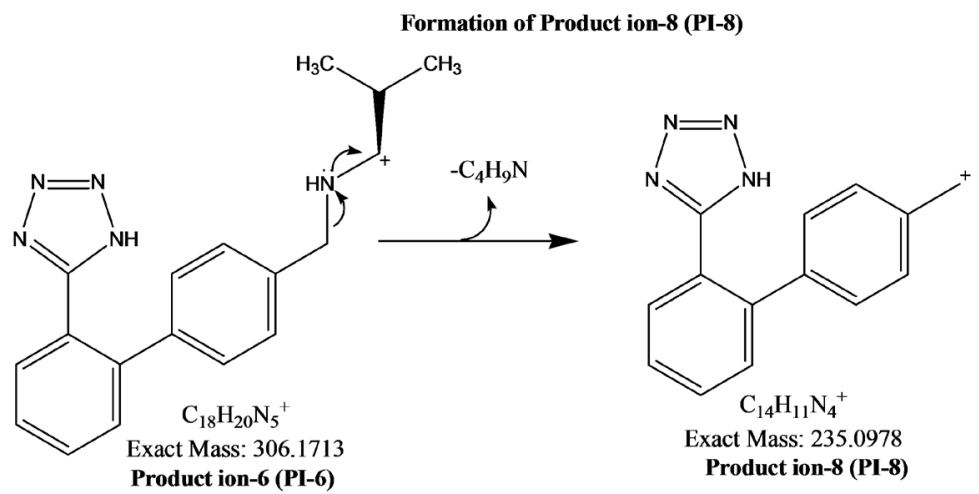

Figure 19. Mechanism for the formation of fragment PI-8.
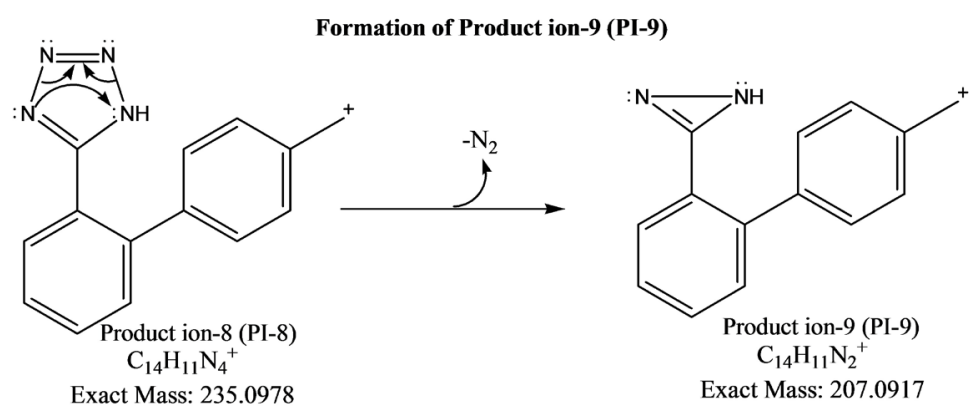

Figure 20. Mechanism for the formation of fragment PI-9.

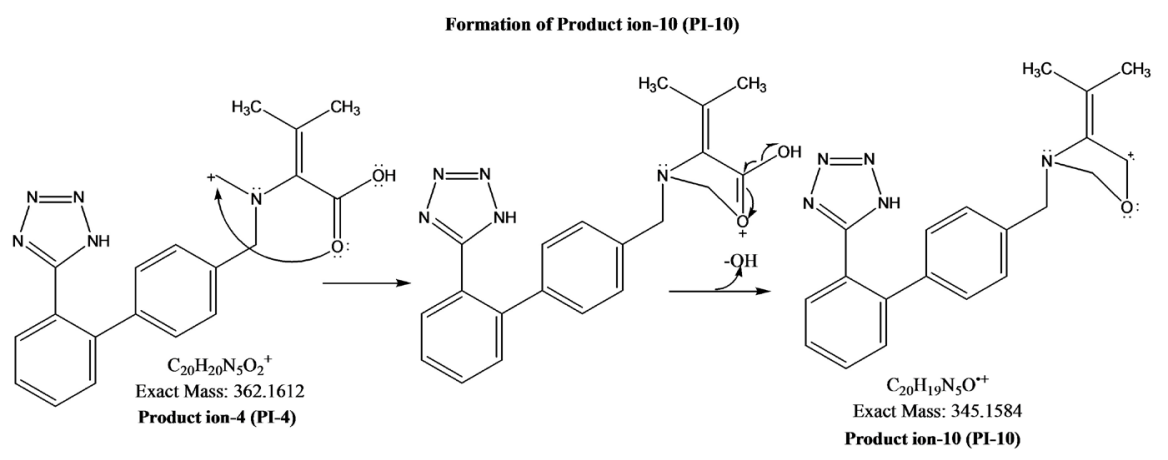

Figure 21. Mechanism for formation of fragment PI-10. 


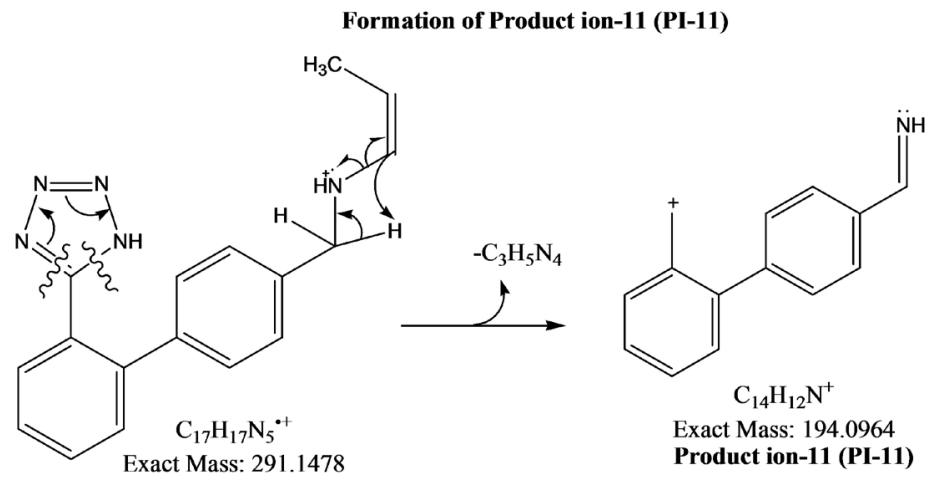

Figure 22. Mechanism for the formation of fragment PI-11.

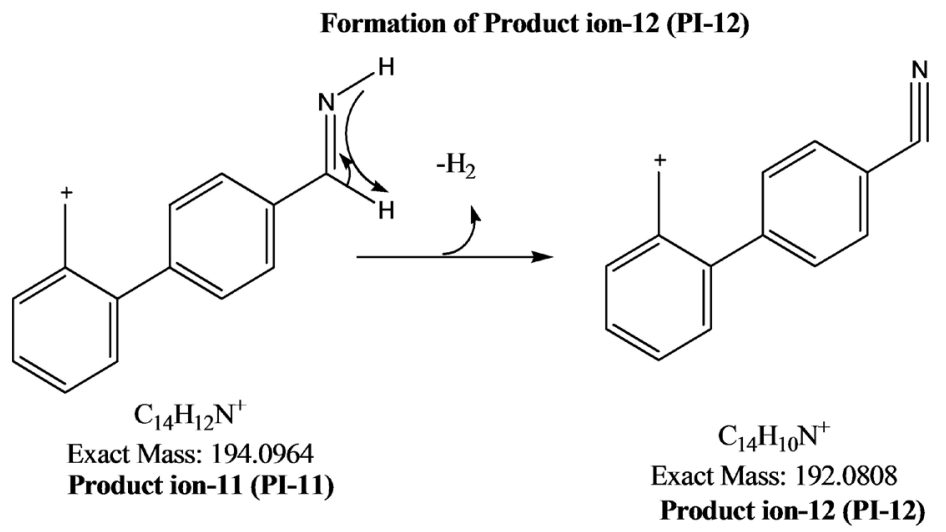

Figure 23. Mechanism for the formation of fragment PI-12.

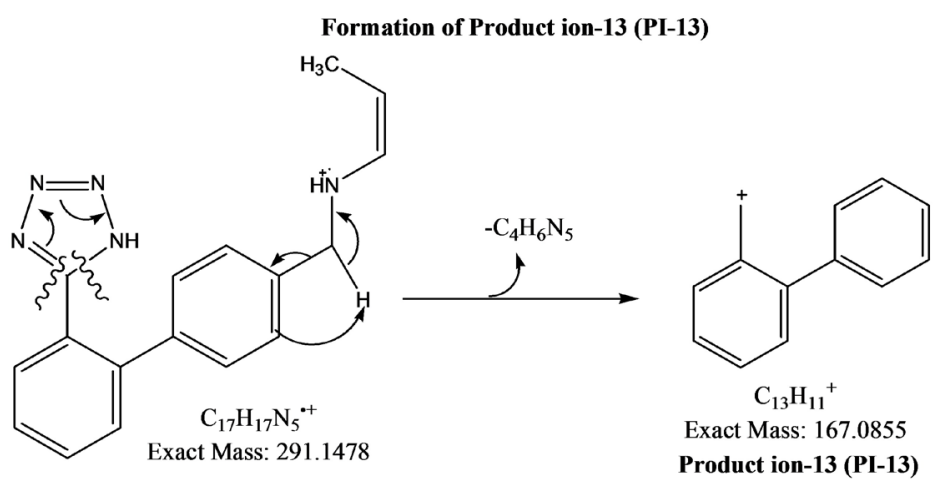

Figure 24. Mechanism for the formation of fragment PI-13.

\section{Conclusion}

During this study, fragment pathway was proposed for the valsartan protonated ion and mechanism for the formation of the signification fragments ions also suggested. The protonated ion peak as $[\mathrm{M}+\mathrm{H}]^{+}$of valsartan appeared at $m / z$ 436. The CID fragmentation of protonated $[\mathrm{M}+\mathrm{H}]^{+}$ion, basic massspectromety interpreation rules and $\mathrm{MS}^{3}$ fragment ions are supporting to the proposed fragmentation pathway. The suggested reaction mechanism will help to designate the mechanism for the similar small molecules, and a fragment ion with similar functional groups, workflow applied in this study was found efficient and can be 
applied for structure verification studies.

\section{Acknowledgements}

This paper is part of the Ph.D. thesis of Dev Kant Shandilya. The author expresses his gratitude to the Dean, Department of Research, Bhagwant University, Ajmer, Rajasthan, India for extending his constant support.

\section{Conflicts of Interest}

The authors declare no conflicts of interest regarding the publication of this paper.

\section{References}

[1] Aksenov, A.A., da Silva, R., Knight, R., Lopes, N.P. and Dorrestein, P.C. (2017) Global Chemical Analysis of Biology by Mass Spectrometry. Nature Reviews Chemistry, 1, 54. https://doi.org/10.1038/s41570-017-0054

[2] Smith, R.M. (2005) Understanding Mass Spectra: A Basic Approach. John Wiley \& Sons Inc., Hoboken, 2.

[3] Pramanik, B.N., Bartner, P.L. and Chen, G. (1999) The Role of Mass Spectrometry in the Drug Discovery Process. Current Opinion in Drug Discovery \& Development, 2, 401-417.

[4] Nicolas, C.E. and Schoolz, T.H. (1998) Active Drug Substances Impurity Profiling Part II. LC-MS/MS Fingerprinting. Journal of Pharmaceutical and Biomedical Analysis, 16, 825-836. https://doi.org/10.1016/S0731-7085(97)00132-5

[5] Cooks, R.G., Chen, G., Wong, P. and Wollnik, H. (1997) Mass Spectrometers. In: Trigg, G.L., Ed., In Encyclopedia of Applied Physics, VCH Publishers, New York, $19,289$.

[6] Chen, G., Pramanik, B.N., Liu, Y.-H. and Mirza, U.A. (2007) Applications of LC/MS in Structure Identifications of Small Molecules and Proteins in Drug Discovery. Journal of Mass Spectrometry, 42, 279-287. https://doi.org/10.1002/jms.1184

[7] Ermer, J. (1998) The Use of Hyphenated LC-MS Technique for Characterization of Impurity Profiles during Drug Development. Journal of Pharmaceutical and Biomedical Analysis, 18, 707-714. https://doi.org/10.1016/S0731-7085(98)00267-2

[8] McLafferty, F.W. and Turecek, F. (1993) Interpretation of Mass Spectra. University of Science Books, Mill Valley, CA.

[9] Angelika, G., Harrison, M.W., Herniman, J.M., Skylaris, C.-K. and Langely, G.J. (2013) A Predictive Science Approach to Aid Understanding of Electrospray Ionization Trandem Mass Spectrometric Fragmentation Pathway of Small Molecules Using Density Functional Calculations. Rapid Communications in Mass Spectrometry, 27, 964-970. https://doi.org/10.1002/rcm.6536

[10] Holcapek, M., Jirasko, R. and Lísa, M. (2010) Basic Rules for the Interpretation of Atmospheric Pressure Ionization Mass Spectra of Small Molecules. Chromatography $A, 1217,3908-3921$. https://doi.org/10.1016/j.chroma.2010.02.049

[11] Johnson, A.R. and Carlson, E.E. (2015) Collision-Induced Dissociation Mass Spectrometry: A Powerful Tool for Natural Product Structure Elucidation. Analytical Chemistry, 87, 10668-10678. https://doi.org/10.1021/acs.analchem.5b01543

[12] Guan, F.Y., Soma, L.R. and Luo, Y. (2006) Collision-Induced Dissociation Pathways 
of Anabolic Steroids by Electrospray Ionization Tandem Mass spectrometry. Journal American Society of Mass Spectrometry, 17, 477-489.

https://doi.org/10.1016/j.jasms.2005.11.021

[13] Dermarque, D.P., Crotti, A.E.M., Vessecchi, R., Lopes, J.L.C. and Lopes, N.P. (2016) Fragmentation Reactions Using Electrospray Ionization Mass Spectrometry: And Important Tool for Structural Elucidation and Characterization of Synthetic and Natural Products. Natural Product Reports, 33, 432.

https://doi.org/10.1039/C5NP00073D

[14] Shandilya, D.K., Israni, R., Joseph, P.E., Kumar, A. and Pillai, M. (2017) Identification of Oxidative Degradation Products of Lansoprazole by Using High Resolution Mass Spectrometry Spectral Data. International Journal of Analytical Mass Spectrometry and Chromatography, 5, 57-69. https://doi.org/10.4236/ijamsc.2017.53004

[15] Shandilya, D.K., Joseph, P.E. and Kantamreddi, V.S.S. (2017) Interpretation of Full Scan Atmospheric Pressure Ionization Mass Spectra (MS) and Collision Induced Dissociation Fragmentation Spectra (MS/MS) of Small Organic Molecules-A Mini Review. Systematic Reviews in Pharmacy, 8, 23-25. https://doi.org/10.5530/srp.2017.1.9

[16] Shandilya, D.K., Joseph, P.E. and Kantamreddi, V.S.S. (2017) Prediction of the Fragmentation Pathway of Atorvastatin by Using High Resolution Collision Induced Dissociation (HR-MS/MS) Spectral Data. Open Access Library Journal, 4, e3473.

[17] https://en.wikipedia.org/wiki/Valsartan

[18] https://www.drugs.com/cdi/valsartan-capsules.html

[19] https://www.rxlist.com/diovan-drug.htm

[20] Shandilya, D.K., Israni, R. and Joseph, P.E. (2018) Prediction of the Fragmentation Pathway of Atorvastatin De-Protonated Ion. Open Access Library Journal, 5, e3473.

\section{Abbreviations Used}

LC: Liquid chromatography; HPLC: High performance liquid chromatography; MS: Mass spectrometry; MS/MS: Tandem mass spectrometer; MS $^{3}$ : Tandem mass spectrometer with trap functionality; $\mathrm{m} / \mathrm{z}$. mass-to-charge ratio; API: Atmospheric pressure ionization; APCI: Atmospheric pressure chemical ionization; ESI: Electrospray ionization; CID: Collision-induced dissociation; FIA: Flow Injection Analysis. 